\title{
Profile analysis of expressed sequence tags derived from the ovary of tilapia, Oreochromis mossambicus
}

\author{
Shian-Ling $\mathrm{Chu}^{\mathrm{a}, 1}$, Ching-Feng Weng ${ }^{\mathrm{c}, 1}$, Chung-Der Hsiao ${ }^{\mathrm{d}}$, Pung-Pung Hwang ${ }^{\mathrm{d}}$, \\ Yun-Ching Chen ${ }^{\text {e }}$, Jan-Ming Ho ${ }^{\text {e }}$, Shyh-Jye Lee ${ }^{\text {a,b,* }}$ \\ anstitute of Zoology, National Taiwan University, 1 Roosevelt Road, Section 4, 209 Fisheries Science Building, Taipei, Taiwan 106, ROC \\ ${ }^{\mathrm{b}}$ Department of Life Sciences, National Taiwan University, 209 Fisheries Science Building, Taipei, Taiwan 106, ROC \\ ${ }^{\mathrm{c}}$ Department of Life Science and Institute of Biotechnology, National Dong Hwa University, Hualien, Taiwan, ROC \\ ${ }^{\mathrm{d}}$ Institute of Zoology, Academia Sinica, Nankang, Taiwan, ROC \\ ${ }^{\mathrm{e}}$ Institue of Information Science, Academia Sinica, Nankang, Taiwan, ROC
}

Received 28 December 2004; received in revised form 28 May 2005; accepted 30 May 2005

\begin{abstract}
Precise regulation of gene expression is required for a proper transition through the different phases of the ovarian cycle. To study ovarian gene expression in teleosts, we constructed an adult ovary cDNA library of tilapia, Oreochromis mossambicus, and analyzed the gene expression profile using an expressed sequence tag-based strategy. Of 768 random clones, 530 clones, with insert lengths of $>100$ base pairs (bp), were assembled into 474 tentative unique genes (TUGs), including 34 contigs and 440 singlets. Among these, 230 TUGs were highly homologous to known genes in public databases, while others exhibited a low sequence homology or no significant matches to known sequences; these are called novel genes here. The abundance of each identified gene was assayed to evaluate its relative importance in ovarian functions. In addition, we analyzed the expression patterns for 6 development-and reproduction-related genes, including cofilin, fibulin-4, glucosamin-6-phosphate deaminase 2 (GNPDA), MCM-6, stathmin, and zona pellucida C5 (ZPC5), as well as 9 novel genes. Results showed that GNPDA, MCM6, ZPC5, and 7 of the novel genes, including O34, O141, O148, O149, O243, O258, and O319, were predominantly expressed in the ovary and/or testis. In addition, the expression patterns of gonad-specific novel genes in tilapia larvae were differentially affected by treatment with $17 \beta$-estradiol and $17 \alpha$-methyltestosterone during the sex-sensitive period. (c) 2005 Elsevier B.V. All rights reserved.
\end{abstract}

Keywords: Oreochromis mossambicus; EST; Ovary; Cofilin; MCM-6; Stathmin

\footnotetext{
* Corresponding author. Institute of Zoology, National Taiwan University, 1 Roosevelt Road, Section 4, 209 Fisheries Science Building, Taipei, Taiwan 106, ROC. Tel.: +886 12 33665902; fax: +8861233662457.

E-mail address: jefflee@ntu.edu.tw (S.-J. Lee).

${ }^{1}$ These two authors contribute equally to this work.
}

\section{Introduction}

The ovary is a female reproductive organ with dual functions: the production of ova and the timely secretion of hormones for regulating growth, development, 
and structural maintenance of animal life. Precise regulation of gene expression is required for the proper transition through different phases of the ovarian life cycle (Richards, 1994). Principally through the study of known genes, we have learned the basics of genes critical for the sequence of the hormone-dependent ovarian cycle. A primordial follicle is initiated in order to assemble extracellular coat proteins, such as zona pellucida 2 and zona pellucida 3, around the oocyte (Millar et al., 1991). An oocyte in the early growth stage expresses specific signaling factors, such as c-kit, a tyrosine kinase receptor (Packer et al., 1994). However, the factor which triggers the growth of primordial oocytes remains unclear. After initiation of early follicular growth, preovulatory follicular growth is mainly regulated by luteinizing hormone (LH) and follicular-stimulating hormone (FSH). LH alone or in cooperation with FSH elicits the growth, atresia, development, ovulation, and ultimately the formation and breakdown of the corpus luteum. The combination of LH and FSH induces highly synchronized and exquisitely timed gene expression for precise control of the ovarian cycle (Richards, 1994). Although, a few LH/FSH downstream effectors, such as adenylyl cyclase (Richards and Rolfes, 1980), are known, the regulatory mechanisms of the ovarian cycle are still far from being fully understood. It is very likely that other undiscovered genes may be involved in the control of ovarian function. In this regard, the expressed sequence tag (EST) strategy is remarkably suitable for the large-scale screening for novel genes and gene expression profile analysis.

EST cloning has been widely applied in a variety of organisms since its first use in the human genomic project (Adams et al., 1991). In addition to gene identification, one advantage of EST analysis is its ability to measure the relative abundance of expressed transcripts, which allows the evaluation of the relative importance of expressed genes. EST libraries of various organs and tissue from teleosts (Davey et al., 2001; Douglas et al., 1999; Gong et al., 1997; Hirono and Aoki, 1997; Inoue et al., 1997; Ju et al., 2000; Karsi et al., 2002; Kocabas et al., 2002; Martin et al., 2002; Zeng and Gong, 2002) have been constructed, including those for tilapia (Hamilton et al., 2000; Shiue et al., 2004). Of particular interest to us, an ovary library was produced for zebrafish (Zeng and Gong, 2002). The ovary cDNA library has yielded a substantial amount of novel genes. In addition, several genes were shown to be specifically expressed in the ovary that may serve as useful molecular markers for the analysis of oogenesis and development.

Oreochromis mossambicus and its close relative, $O$. niloticus, are important fish species for both research and aquaculture. Tilapia are the second most important food fish, next to carp worldwide. They are also excellent laboratory animals because (1) they have a short generation time of $6 \sim 7$ months, (2) the embryos and fry are easily obtained and reared in laboratory, and (3) transgenic animals can be produced relatively easily (Maclean et al., 2002). Despite their importance to fisheries, studies of their genome are still very preliminary and far behind other fish species like zebrafish or medaka. In addition, the feasibility of controlling the sexual differentiation by various methodologies, including genetics, changes in the environment, and drug treatments, make tilapia favorable models for the functional study of gonads. Therefore, in this study, we sequenced and analyzed 768 EST clones derived from an ovary cDNA library of adult $O$. mossambicus and identified 474 tentative unique genes. In addition, we also analyzed 6 development- and reproduction-related genes and 9 novel genes for their gene expression patterns. Furthermore, the expression patterns of 6 gonad-specific novel genes under the influences of $17 \alpha$-methyltestosterone and $17 \beta$-estradiol were also analyzed during the sex differentiation-sensitive period from days 24 to 33 after fertilization. The establishment of the gene profile and its analysis of this tilapia ovary cDNA library are thus proving to be a fruitful gene identification source, which will benefit research of ovarian functions and sex differentiation of tilapia as well as other economically important cultured fishes.

\section{Materials and methods}

\subsection{Construction of a cDNA library}

Adults of $O$. mossambicus were obtained from the Mariculture Research Center, Fisheries Research Institute, Tainan, Taiwan. PolyA ${ }^{+}$RNA was extracted using the NucleoTrap ${ }^{\circledR}$ mRNA Kit (BD Biosciences Clontech) from the ovaries of 3 females. One-half microgram of polyA ${ }^{+}$RNA was utilized for the construction 
of the library using a Creator ${ }^{\mathrm{TM}}$ SMART $^{\mathrm{TM}}$ cDNA Library Construction Kit (BD Biosciences Clontech) according to the manufacturer's instructions. The titer of the primary cDNA libraries was about $1.5 \times 10^{6} \mathrm{cfu}$, and 5000 primary clones were randomly picked and stored in 96-well plates at $-80{ }^{\circ} \mathrm{C}$.

\subsection{Selection, sequencing, and size determination of cDNA clones}

The cDNA clones of the primary library were randomly selected for single-pass 5 'sequencing. Double-stranded DNA sequencing was carried out using the BaseStation ${ }^{\text {TM }}$ DNA Fragment Analyzer (MJ Re- search Base Station). Each clone was sequenced once from the $5^{\prime}$ end using the vector sequencing primer pDNR-F (5'TTATACGAAGTTATCAGTCGAC-3). To evaluate the size of the insert in a cDNA clone, the inserted DNA fragments of plasmids isolated from each individual colony were amplified by PCR using the M13 sequencing primer pair (forward, 5' GTAAAACGACGGCCAGT-3' and reverse, 5'AAACAGCTATGACCATGTTCA). PCR amplification was performed in a $10-\mu 1$ reaction volume with the thermostable DNA polymerase (TaKaRa Taq ${ }^{\mathrm{TM}}$, TaKaRa Biochemicals). PCR was performed using a thermal cycler (PTC-200, MJ Research) for 25 cycles according to the following protocol: denaturation at

Table 1

Primer sequences for each gene used in the analysis of the temporal and spatial gene expression patterns by RT-PCR

\begin{tabular}{|c|c|c|}
\hline Group ID* & Gene annotation & Primer sequences \\
\hline \multirow[t]{2}{*}{ TO_TUS_217 } & \multirow[t]{2}{*}{ cofilin } & Forward: 5'-GATCATCGTGGAAGAGGGAA-3' \\
\hline & & Reverse: 5'GAGACATCACAGCTGCTTGC-3' \\
\hline \multirow[t]{2}{*}{ TO_TUS_293 } & \multirow[t]{2}{*}{ fibulin-4 } & Forward: 5'GAGTGTACGGAGACGCAGAACT-3' \\
\hline & & Reverse: 5'AATGGACACCCATCTCCAGGTC-3' \\
\hline \multirow[t]{2}{*}{ TO_TUS_13 } & \multirow[t]{2}{*}{ glucosamin-6-phosphate deaminase 2} & Forward: 5'GTCGACATGAGGCTGGTCATTCTC-3' \\
\hline & & Reverse: 5'GGATTCCTGGTCTTTTATGCTGAGC-3' \\
\hline \multirow[t]{2}{*}{ TO_TUS_356 } & \multirow[t]{2}{*}{ MCM6 } & Forward: 5'TGGATGAGATCCGCAGATACCT-3' \\
\hline & & Reverse: 5'GCGAAAGACAGACGCAGAGAT-3' \\
\hline \multirow[t]{2}{*}{ TO_TUS_437 } & \multirow[t]{2}{*}{ stathmin } & Forward: 5-GTCGACATGGCAGCCGCTGAAGATA-3' \\
\hline & & Reverse: 5'GGATTCGCCTCCATCTTCTGGTTGA-3' \\
\hline \multirow[t]{2}{*}{ TO_TUS_10 } & \multirow[t]{2}{*}{ ZPC5 } & Forward: 5'CCTCAGTCAGAGTTGGACAT-3' \\
\hline & & Reverse: 5'GTGTAGCAGTCAGGAGCAGT-3' \\
\hline \multirow[t]{2}{*}{ TO_TUS_34 } & \multirow[t]{2}{*}{$\mathrm{O} 34$} & Forward: 5'GAAGGATGCAGAGATGCCTGTTAC-3' \\
\hline & & Reverse: 5-TGACAGACCGTGAGCTCGAATT-3' \\
\hline \multirow[t]{2}{*}{ TO_TUS_62 } & \multirow[t]{2}{*}{ O62 } & Forward: 5'AACGACAGTGTCAGGAAAAACCC-3' \\
\hline & & Reverse: 5'GGTGAGTCCAGGTGAGGAAACATA-3' \\
\hline \multirow[t]{2}{*}{ TO_TUS_141 } & \multirow[t]{2}{*}{ O141 } & Forward: 5'ATCACTGGATGGAAAATAGTGA-3' \\
\hline & & Reverse: 5'TGATGTGGGCCTTAAACC-3' \\
\hline \multirow[t]{2}{*}{ TO_TUS_148 } & \multirow[t]{2}{*}{$\mathrm{O} 148$} & Forward: 5'ACCTGAGGGAGAGAACGGGG-3' \\
\hline & & Reverse: 5'GTAGCACCTGGAGGTGAAGGG-3' \\
\hline \multirow[t]{2}{*}{ TO_TUS_149 } & \multirow[t]{2}{*}{$\mathrm{O} 149$} & Forward: 5'GGGGGAAACTCATTATTTTCT-3' \\
\hline & & Reverse: 5'AGGAAGACAAATCCTGTTTTAAA-3' \\
\hline \multirow[t]{2}{*}{ TO_TUS_175 } & \multirow[t]{2}{*}{$\mathrm{O} 175$} & Forward: 5'GCAGGATCACAACCAGGTCAAT-3' \\
\hline & & Reverse: 5'AGACGTTCGACGAGATAGCTGG-3' \\
\hline \multirow[t]{2}{*}{ TO_TUS_243 } & \multirow[t]{2}{*}{$\mathrm{O} 243$} & Forward: 5'GGAGGCTGAGAAACGGAAAGC-3' \\
\hline & & Reverse: 5'GATGTCGTCGTCGCCATCTG-3' \\
\hline \multirow[t]{2}{*}{ TO_TUS_258 } & \multirow[t]{2}{*}{$\mathrm{O} 258$} & Forward: 5'ACGGTGTATGGAGTGAGGTAATGC-3' \\
\hline & & Reverse: 5'GGCTTATCCTGGAGTTTAGGCTTC-3' \\
\hline \multirow[t]{2}{*}{ TO_TUS_319 } & \multirow[t]{2}{*}{$\mathrm{O} 319$} & Forward: 5'GCAAAGGATGCAGTGGAGGAC-3' \\
\hline & & Reverse: 5'CGAGCTGTCAGGATCACGTCA-3' \\
\hline \multirow[t]{2}{*}{ AB037865 (Genbank No.) } & $\beta$-actin & Forward: 5'ACCACCACAGCCGAGAGGGA-3' \\
\hline & & Reverse: 5'-TTGTTGGGCGTTTGGTTGGG-3' \\
\hline
\end{tabular}

* Group ID is the identification number used at the tilapia ovary sequence web site (http://140.109.18.216/ public/EST_Analysis/public/ tilapia/ovary/index.htm). 


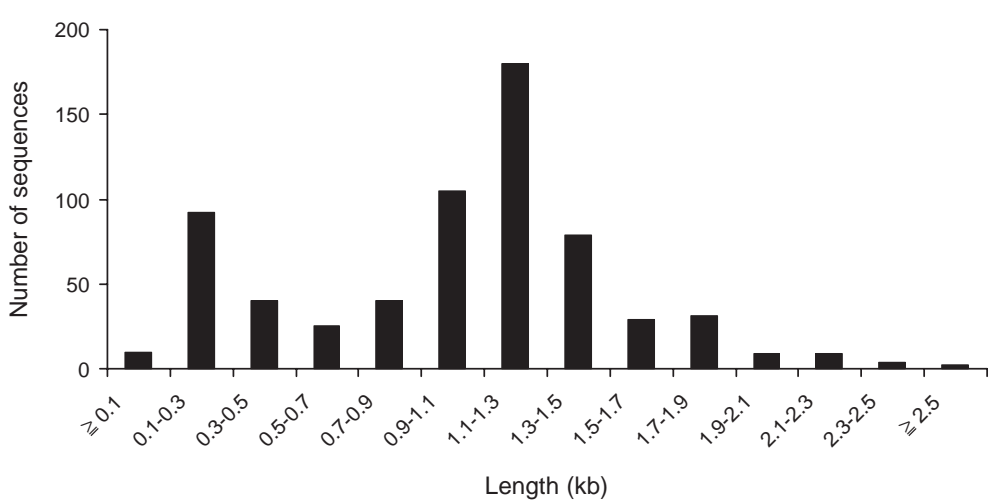

Fig. 1. Insert size distribution of clones isolated from a cDNA library of the tilapia ovary. The cDNA clone insert size was determined by PCR as described in "Materials and methods". We successfully determined the insert sizes of 665 clones and found that most clones (643) had an insert size of between 0.1 and $2.5 \mathrm{~kb}$. The most-abundant groups (55.6\%) were clones with insert sizes ranging from 0.9 to $1.5 \mathrm{~kb}$, and $14 \%$ clones had an insert size of $0.1 \sim 0.3 \mathrm{~kb}$.

$94{ }^{\circ} \mathrm{C}$ for $30 \mathrm{~s}$, annealing at $45{ }^{\circ} \mathrm{C}$ for $30 \mathrm{~s}$, and elongation at $72{ }^{\circ} \mathrm{C}$ for $1.5 \mathrm{~min}$.

\subsection{Sequence analysis and annotation}

After elimination of the vector sequences and correction of obvious reading errors, all sequences larger than $100 \mathrm{bp}$ were submitted to the Bioinformatics Center (National Yang-Ming University, Taipei, Taiwan) for further analysis. Identification of a homologous cDNA clone was based on the e-value reported in the blast results against selected NR databases, including Non-redundant GenBank CDS translations, PDB, SwissProt, PIR, and PRF. An identified clone generally has a matching sequence e-value of $<10^{-10}$. A clone containing the complete coding region was identified from the $5^{\prime}$ EST sequence covering the start and stop codons of a matching sequence. Reverse sequencing from the $3^{\prime}$ end was performed as necessary to obtain the complete coding region sequence. Using the BGSSJ20040204 software developed by the Institute of Information Science (Academia Sinica, Taipei, Taiwan), we first collected UniGene accession numbers for known TUGs from the NCBI UniGene database (available at http://www.ncbi.nlm.nih.gov/entrez/query. fcgi?db=unigene). Second, we obtained gene ontology information of each TUG according to its UniGene accession number or symbol in the Gene Ontology Consortium (available at http://www.geneontology. org/). If no gene ontology information was available for the matching sequence with the highest score, the gene ontology was determined according to the next matching sequence and so on until the matching sequence's e-value exceeded $10^{-10}$.

\subsection{Animal husbandry and hormonal treatments of tilapia larvae}

Adult tilapia (O. mossambicus) were reared in a freshwater tank at $24 \sim 28{ }^{\circ} \mathrm{C}$. Fertilized eggs were collected from mouth-brooding females and kept in a $28{ }^{\circ} \mathrm{C}$ freshwater tank with sufficient aeration. Five

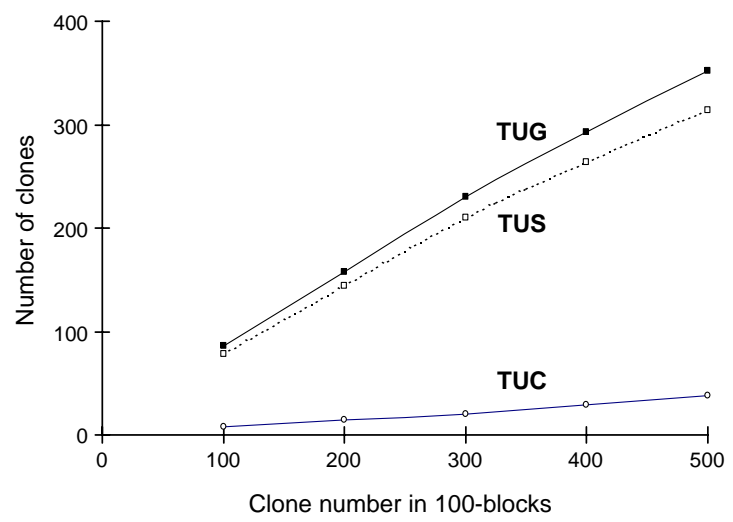

Fig. 2. Increase in identifiable tentative unique genes (TUGs) with the number of clones sequenced in the tilapia ovary cDNA library. Numbers of tentative unique contigs (TUCs), tentative unique singlets (TUSs), and TUGs are plotted against the numbers of clone sequenced. TUGs and TUSs increased rapidly with an increase in the number of clones sequenced, but the TUCs increased much more slowly. 
days after hatching, larvae were subdivided into 3 groups. Larvae were fed regular feed with the following ingredients: $16 \%$ fish meal, $30 \%$ rice bran, $25 \%$ lupin seed meal, $20 \%$ wheat flour, $3.4 \%$ fish oil, $1 \%$ vitamin mix, $4 \%$ mineral mix, $0.5 \%$ choline chloride, and $0.1 \%$ vitamin E (50\% purity). For the 2 experimental groups, larvae received additives of 100 mg $17 \beta$-estradiol $\left(\mathrm{E}_{2}\right)$ per $\mathrm{kg}$ feed during days 7 20 or $100 \mathrm{mg} 17 \alpha$-methyltestosterone (MT) per kg feed during days $10 \sim 20$, respectively.

\subsection{Gene expression analysis using $R T-P C R$}

Six development-and reproduction-related clones and 9 novel genes were selected for analysis of tissue-specific and temporal gene expression. The tissue expression patterns of the selected genes were determined by RT-PCR using the primers listed in Table 1. Total RNAs were prepared using the Trizol reagent (Invitrogen) from different adult tilapia tissues and fry at designated stages. For synthesizing single-stranded

Table 2

List of 25 identified clones containing the complete coding sequences from an Oreochromis mossambicus ovary cDNA library

\begin{tabular}{|c|c|c|c|c|c|c|c|}
\hline \multicolumn{3}{|c|}{ Tilapia ovary ESTs } & \multicolumn{5}{|c|}{ Matching sequences } \\
\hline $\begin{array}{l}\text { Accession } \\
\text { number }\end{array}$ & Putative annotation & $\begin{array}{l}\text { Functional } \\
\text { class }\end{array}$ & $\begin{array}{l}\text { Accession } \\
\text { number }\end{array}$ & Species & E-value & $\begin{array}{l}\text { Identity } \\
(\%)\end{array}$ & $\begin{array}{l}\text { Overlap/total } \\
\text { amino acids }\end{array}$ \\
\hline AY737028 & $\begin{array}{l}\text { CCR4-NOT transcription complex, } \\
\text { subunit } 7\end{array}$ & 1 & AAH07315.1 & Homo sapiens & $6 e-38$ & 90 & $84 / 246$ \\
\hline AY737029 & $\begin{array}{l}\text { Unnamed protein } \\
\text { product/ CKN1 protein }\end{array}$ & 1,5 & CAG10886.1 & $\begin{array}{l}\text { Tetraodon } \\
\text { nigroviridis }\end{array}$ & $1 \mathrm{e}-127$ & 89 & $221 / 247$ \\
\hline AY737031 & Copper chaperone & 1 & AAF01286.1 & Canis familiaris & $5 e-17$ & 58 & $68 / 68$ \\
\hline AY737032 & CUTL1 protein & $1,3,4$ & AAH66592.1 & Homo sapiens & $8 \mathrm{e}-72$ & 91 & $104 / 1516$ \\
\hline AY737033 & $\begin{array}{l}\text { Cytochrome c oxidase subunit IV } \\
\text { isoform 2, mitochondrial precursor }\end{array}$ & 1 & AAF79934.1 & Thunnus obesus & $3 e-61$ & 62 & $110 / 176$ \\
\hline AY737034 & D7-like protein & 13 & AAC63308.1 & Perca flavescens & $4 e-52$ & 56 & $150 / 152$ \\
\hline AY737035 & $\begin{array}{l}\text { Unnamed protein product/similar } \\
\text { to DNA polymerase delta subunit } 3\end{array}$ & 1,2 & CAF97746.1 & $\begin{array}{l}\text { Tetraodon } \\
\text { nigroviridis }\end{array}$ & $1 \mathrm{e}-120$ & 53 & $250 / 467$ \\
\hline AY737036 & Niemann-Pick disease, type $\mathrm{C} 2$ & 13 & NP_775331.1 & Danio rerio & $2 \mathrm{e}-53$ & 66 & $148 / 149$ \\
\hline AY737037 & F-box only protein 36 & 13 & NP_079662.1 & Mus musculus & $1 \mathrm{e}-18$ & 50 & $82 / 188$ \\
\hline AY737038 & G10 protein & 1 & AAT68045.1 & Danio rerio & $9 \mathrm{e}-72$ & 93 & $126 / 135$ \\
\hline AY737040 & Hypothetical protein LOC90624 & 13 & NP_859056.1 & Homo sapiens & $2 \mathrm{e}-25$ & 54 & $103 / 104$ \\
\hline AY737041 & Hypothetical protein MGC64043 & 13 & NP_956664.1 & Danio rerio & $4 \mathrm{e}-31$ & 53 & $118 / 124$ \\
\hline AY737043 & glucosamine-6-phosphate deaminase 2 & 1,4 & NP_612208.1 & Homo sapiens & $2 \mathrm{e}-95$ & 79 & $211 / 276$ \\
\hline AY737044 & Microsomal glutathione S-transferase & 13 & AAL12230.1 & $\begin{array}{l}\text { Oryctolagus } \\
\text { cuniculus }\end{array}$ & $3 e-48$ & 68 & $139 / 152$ \\
\hline AY737045 & Mitochondrial carrier homolog 2 & 2 & NP_571457.1 & Danio rerio & $1 e-148$ & 83 & $300 / 300$ \\
\hline AY737046 & $\begin{array}{l}\text { Unnamed protein product/similar to } \\
\text { myo-inositol monophosphatase }\end{array}$ & 1 & CAG05496.1 & $\begin{array}{l}\text { Tetraodon } \\
\text { nigroviridis }\end{array}$ & $1 \mathrm{e}-128$ & 80 & $227 / 283$ \\
\hline AY737047 & Myosin light chain $(19.9 \mathrm{kD})$ & 4,7 & NP_999864.1 & Danio rerio & $9 e-91$ & 94 & $163 / 172$ \\
\hline AY737048 & $\begin{array}{l}\text { Proteasome (prosome, macropain) } \\
\text { subunit, alpha type } 1\end{array}$ & 1,2 & NP_036095.1 & Mus musculus & $1 \mathrm{e}-82$ & 93 & $153 / 263$ \\
\hline AY737049 & Selenoprotein W2a & 13 & NP_919398.1 & Danio rerio & $1 \mathrm{e}-34$ & 72 & $92 / 92$ \\
\hline AY737051 & Similar to small acidic protein & 13 & NP_956488.1 & Danio rerio & $3 e-35$ & 74 & $74 / 100$ \\
\hline AY737053 & $\begin{array}{l}\text { Unnamed protein } \\
\text { product } / \mathrm{Tm} 4 \text { sf3-prov protein }\end{array}$ & 1 & CAG12382.1 & $\begin{array}{l}\text { Tetraodon } \\
\text { nigroviridis }\end{array}$ & $6 e-51$ & 46 & $224 / 225$ \\
\hline AY737054 & Trappc3-prov protein & 2 & AAH53802.1 & Xenopus laevis & $1 \mathrm{e}-18$ & 87 & $49 / 180$ \\
\hline AY737059 & $\begin{array}{l}\text { SI:bZ1F1.7 (novel protein similar to } \\
\text { human AKAP-associated sperm } \\
\text { protein (ASP) }\end{array}$ & 13 & CAE17582.1 & Danio rerio & $5 e-70$ & 65 & $198 / 212$ \\
\hline AY737060 & $\begin{array}{l}\text { Unnamed protein product } \\
\text { (BAB27540)/ CDC28 protein kinase } 1\end{array}$ & 1,2 & BAB27540.1 & Mus musculus & $2 \mathrm{e}-28$ & 78 & $74 / 49$ \\
\hline AY737062 & $\begin{array}{l}\text { zgc: } 55453 / \text { compass (complex proteins } \\
\text { associated with Set1p) component }\end{array}$ & 1,2 & NP_955845.1 & Danio rerio & $1 \mathrm{e}-104$ & 90 & $180 / 198$ \\
\hline
\end{tabular}


cDNAs, $3 \mu \mathrm{g}$ of total RNA, oligo dT primers, and the M-MLV Reverse Transcriptase (Promega) were applied in a total reaction volume of $25 \mu \mathrm{l}$. RT-PCR was performed with respective primers for 25 30 cycles following the PCR protocols described previously at the optimal annealing temperatures of $46 \sim 60{ }^{\circ} \mathrm{C}$.

\section{Results}

\subsection{Summary of EST clones in the tilapia ovary cDNA library}

In total, 768 random clones from the tilapia, $O$. mossambicus, ovary cDNA library were partially sequenced from the $5^{\prime}$ end, and the insert sizes were determined by PCR, among which, 665 clones were successfully determined. Most clones (643) contained an insert of between 0.1 and $2.5 \mathrm{~kb}$. The most-abundant clone insert sizes ranged $0.9 \sim 1.5 \mathrm{~kb}(364,55.6 \%)$ and $0.1 \sim 0.3 \mathrm{~kb}(92,14 \%)$ (Fig. 1). After vector sequence trimming, $69 \%$ (530) of the EST sequences were found to exceed $100 \mathrm{bp}$ in length. These EST sequences were then subjected to further analysis and assembled into the tentative unique contigs (TUCs) and singlets (TUSs). The assembly of TUCs and TUSs forms the tentative unique genes (TUGs). To evaluate the potential of this ovary library to supply identifiable TUGs, we analyzed the efficiency of gene discovery for every 100 clones as shown in Fig. 2. For the first 500 clones, numbers of TUSs and TUGs rapidly increased with a slight rise in the number of TUCs. The percent TUGs of sequenced clones gradually decreased from $86.0 \%$ to $70.4 \%$, which was due to the repeat sequences of the same genes. The percent TUCs of sequenced clones remained relatively constant from $6.8 \%$ to $8.0 \%$. In total, 530 EST sequences were assembled into 34 TUCs and 440 TUSs. These TUCs and TUSs were compared by blasting against all non-redundant GenBank CDS translations, PDB, SwissProt PIR and PRF, which resulted in 230 TUGs (274 clones, with an expected threshold value of $<10^{-10}$ ). The cDNA identification rate was $52 \%$ (274 of 530 clones). Among the identified cDNAs, $10.9 \%$ (25 of 230 ) TUGs contained the complete protein coding region with identified start and stop codons when compared to known genes. Sequences of those clones have been submitted to GenBank as listed in Table 2. Table 2 shows the gene accession numbers with details of the most-closely matched sequence species along with homology values and functional classifications as described below. All other sequences are available at http://140.109.18. 216/ public/EST_Analysis/public/tilapia/ovary/index. htm, which is built and maintained at the Institute of Information Science, Academia Sinica, Taipei, Taiwan.

\subsection{Functional categorization of the identified tilapia ovary TUGS}

In total, 230 identified TUGs were classified into 13 broad biological process categories according to the Gene Ontology Consortium (available at http:// www.geneontology.org/), and numbers of TUGs in the various categories are presented in Table 3. Because a gene may have multiple possible functions, some TUGs were assigned to more than 1 category. Apart from those genes with unclassified functions $(30 \%, 69 / 230)$, the largest group of TUGs was allocated to metabolism $(41.7 \%, 96 / 230)$, followed by cell growth and/or maintenance $(25.7 \%, 59 / 230)$, cell communication and differentiation $(7.8 \%, 18 / 230)$, development and reproduction $(6.5 \%, 15 / 230)$,

Table 3

Functional distribution of identified tentative unique genes (TUGs) in the ovary library

\begin{tabular}{lll}
\hline Number & Category $^{\text {a }}$ & $\begin{array}{l}\text { Number } \\
\text { of TUGs }\end{array}$ \\
\hline 1 & Metabolism & 96 \\
2 & Cell growth and/or maintenance & 59 \\
3 & Cell communication and differentiation & 18 \\
4 & Development and reproduction & 15 \\
5 & Response to stress or stimulus & 6 \\
6 & Homeostasis & 4 \\
7 & Cell motility & 3 \\
8 & Behavior & 3 \\
9 & Death & 2 \\
10 & Secretion & 2 \\
11 & mRNA splicing & 1 \\
12 & Obsolete biological process & 1 \\
13 & Unclassified & 69 \\
\hline a The category classification was based on the Gene Ontology \\
Consortium (available at http://www.geneontology.org/) & as de- \\
scribed in "Materials and methods".
\end{tabular}


responses to stresses or stimuli $(2.6 \%, 6 / 230)$, homeostasis $(1.7 \%, 4 / 230)$, cell motility $(1.3 \%, 3 / 230)$, behavior $(1.3 \%, 3 / 230)$, death $(0.8 \%, 2 / 230)$, secretion $(0.8 \%, 2 / 230)$, and single appearances of a gene involved in mRNA splicing and a gene for an obsolete biological process, respectively.

\subsection{Analysis of gene abundances of the identified tilapia ovary TUGS}

The most-abundant TUGs, which appeared at least twice among the cDNA clones analyzed, in the ovary library are summarized in Table 4 . These abundant

Table 4

Most-abundant ovary cDNA clones

\begin{tabular}{|c|c|c|c|c|c|c|c|c|}
\hline \multicolumn{4}{|c|}{ Tilapia ovary ESTs } & \multicolumn{5}{|c|}{ Matching sequences } \\
\hline $\begin{array}{l}\text { Accession } \\
\text { number }\end{array}$ & Putative annotation & Frequency & $\begin{array}{l}\text { Functional } \\
\text { class }\end{array}$ & $\begin{array}{l}\text { Accession } \\
\text { number }\end{array}$ & Species & E-value & $\begin{array}{l}\text { Identity } \\
(\%)\end{array}$ & $\begin{array}{l}\text { Overlap/total } \\
\text { amino acids }\end{array}$ \\
\hline \multicolumn{9}{|c|}{ Housekeeping genes } \\
\hline AY737014 & Quinone reductase & 7 & 1 & AAD38913.1 & Oryzias latipes & $2 e-36$ & 65 & $117 / 270$ \\
\hline AY737036 & Niemann-Pick disease, type C2 & 5 & 13 & NP_775331.1 & Danio rerio & $2 e-53$ & 66 & $148 / 149$ \\
\hline AY737015 & Arylamine $\mathrm{N}$-acetyl transferase & 3 & 1 & P13913 & Gallus gallus & $6 e-60$ & 50 & $222 / 290$ \\
\hline AY737055 & Ubiquitin & 3 & 1 & EAK88214.1 & $\begin{array}{l}\text { Cryptosporidium } \\
\text { parvum }\end{array}$ & $2 \mathrm{e}-77$ & 92 & $154 / 167$ \\
\hline AY737016 & XNop56 protein & 3 & 2 & CAC44272.1 & Xenopus laevis & $4 e-35$ & 85 & $85 / 532$ \\
\hline AY737044 & $\begin{array}{l}\text { Microsomal glutathione } \\
\text { S-transferase }\end{array}$ & 2 & 13 & AAL12230.1 & $\begin{array}{l}\text { Oryctolagus } \\
\text { cuniculus] }\end{array}$ & $3 e-48$ & 68 & $139 / 152$ \\
\hline AY737017 & $\begin{array}{l}\text { Proteasome endopeptidase } \\
\text { complex chain XC8 }\end{array}$ & 2 & 1 & S38529 & Xenopus laevis & $1 \mathrm{e}-71$ & 88 & $133 / 151$ \\
\hline AY737018 & $\begin{array}{l}\text { Pyruvate dehydrogenase } \\
\text { lipoamide alpha } 1\end{array}$ & 2 & 1 & AAH60928.1 & Danio rerio & $1 \mathrm{e}-100$ & 88 & $117 / 393$ \\
\hline AY737019 & $\begin{array}{l}\text { Unknown protein for } \\
\text { MGC: } 77119 / \text { pan-epithelial } \\
\text { glycoprotein }\end{array}$ & 2 & $2,3,5$ & AAH66716.1 & Danio rerio & $4 e-73$ & 61 & $214 / 302$ \\
\hline AY737020 & $\begin{array}{l}\text { Zgc: } 77127 \\
\text { protein/thioredoxin } 2\end{array}$ & 2 & 2,6 & AAH65316.1 & Danio rerio & $3 e-51$ & 67 & $104 / 155$ \\
\hline \multicolumn{9}{|c|}{ Non-house keeping genes } \\
\hline AY737021 & $\begin{array}{l}\text { Ferritin, middle subunit } \\
\text { Ferritin } \mathrm{M}\end{array}$ & 4 & 2,6 & AAB34576.1 & Salmo salar & $7 e-52$ & 89 & $97 / 108$ \\
\hline AY737022 & $\begin{array}{l}\text { Unknown protein for } \\
\text { MGC:56095/Ferritin } \\
\text { lower subunit }\end{array}$ & 2 & $2,5,6$ & AAH45905.1 & Danio rerio & $3 e-66$ & 68 & $172 / 179$ \\
\hline AY737060 & $\begin{array}{l}\text { Unnamed protein product } \\
(\text { dbj|BAB27540.1|)/CDC28 } \\
\text { protein kinase } 1\end{array}$ & 4 & 1,2 & BAB27540.1 & Mus musculus & $2 \mathrm{e}-28$ & 78 & $74 / 49$ \\
\hline AY737023 & G2 mitotic-specific cyclin B & 2 & 2 & P07818 & Xenopus laevis & $8 e-63$ & 86 & $115 / 255$ \\
\hline AY737024 & Calmodulin & 2 & 2,3 & AAO17827.1 & $\begin{array}{l}\text { Paralichthys } \\
\text { olivaceus }\end{array}$ & $3 e-17$ & 100 & $43 / 65$ \\
\hline AY737047 & myosin light chain (19.9 kD) & 2 & 4,7 & NP_999864.1 & Danio rerio & $9 e-91$ & 94 & 163.172 \\
\hline AY737034 & D7-like protein/KLRL1 & 2 & 13 & AAC63308.1 & Perca flavescens & $4 e-52$ & 56 & $150 / 152$ \\
\hline AY737025 & Interleukin-12 p40 & 3 & 3 & BAC81423.1 & Takifugu rubripes & $4 e-23$ & 51 & $105 / 359$ \\
\hline AY737026 & $\begin{array}{l}\text { Codedfor by human cDNAs } \\
\text { W37389(gb| AAB46345.1|)/ } \\
\text { ocular development } \\
\text { associated gene }\end{array}$ & 2 & 13 & AAB46345.1 & Homo sapiens & $3 e-26$ & 88 & $58 / 140$ \\
\hline AY737027 & $\mathrm{ZPC} 1$ & 3 & 13 & AAN31188.1 & Oryzias latipes & $1 e-47$ & 61 & $82 / 134$ \\
\hline AY737039 & $\begin{array}{l}\text { Hypothetical protein } \\
\text { BC012173/ Elongator } \\
\text { associated protein }\end{array}$ & 2 & 1,2 & CAG13120.1 & $\begin{array}{l}\text { Tetraodon } \\
\text { nigroviridis }\end{array}$ & $2 e-52$ & 80 & $95 / 118$ \\
\hline
\end{tabular}


TUGs are comprised of 59 clones representing 11.1\% (59/530) of the analyzed clones. About half of these abundant TUGs $(47.6 \%, 10 / 21)$ are housekeeping genes, such as quinone reductase, arylamine $\mathrm{N}$-acetyl transferase, Niemann-Pick disease type $\mathrm{C} 2$ protein, an ubiquitin precursor, XNop56 protein, proteasome endopeptidase complex chain XC8, pyruvate dehydrogenase lipoamide alpha 1, pan-epithelial glycoprotein, microsomal glutathione S-transferase, and thioredoxin 2. The remaining 11 genes (called non-housekeeping genes), including ferritin and others, may play functional roles in the ovary and are discussed in the "Discussion" section.

\subsection{Tissue distribution analyses of selected develop- ment-and reproduction-related genes}

We were particularly interested in genes which may be involved in the regulation of ovarian functions. Therefore, 6 genes allocated to the development and reproduction category were selected from this ovary library in order to analyze their expression patterns in different adult tilapia tissues by RT-PCR (Fig. 3). Cofilin was expressed in all tissues, but was much lower in the liver. Fibulin-4 was mainly expressed in the heart and only slightly in the skeletal muscle, kidney, spleen, and gill. Glucosamin-6-phosphate deaminase 2 (GNPDA/oscillin) was strongly expressed in the testis and was much weaker in other tissues except the intestine. MCM6 was strongly expressed in the ovary and testis where strong replication activities occur and was also strongly expressed in eye. Stathmin was strongly expressed in the brain, eye, ovary, testis, and heart but showed lower expression in the skeletal muscle, kidney, and spleen. ZPC5 was specifically expressed in the ovary, but not in other tissues, which further confirms its role as an oocyte-specific component. An RT-PCR of $\beta$-actin, a housekeeping gene, was also performed to serve as an expression control among different tissues.

\subsection{Spatial and temporal expression of novel ovary- derived genes}

More than half of the TUGs identified in this tilapia ovary library lacked a significant match with known gene sequences. To study the expression of those potential novel genes, we selected 9 clones with an insert size exceeding $500 \mathrm{bp}$ for the RTPCR analysis in different adult tissues. As shown in Fig. 4, all genes were strongly expressed in the ovary except for O62, which was only slightly expressed; most genes were expressed in the testis as well except for O34; genes were also sparingly expressed in other tissue with wider expressions exhibited by $\mathrm{O} 149$ and $\mathrm{O} 319$.

We further examined the expression patterns of 6 gonad-specific novel genes during the sex-sensitive

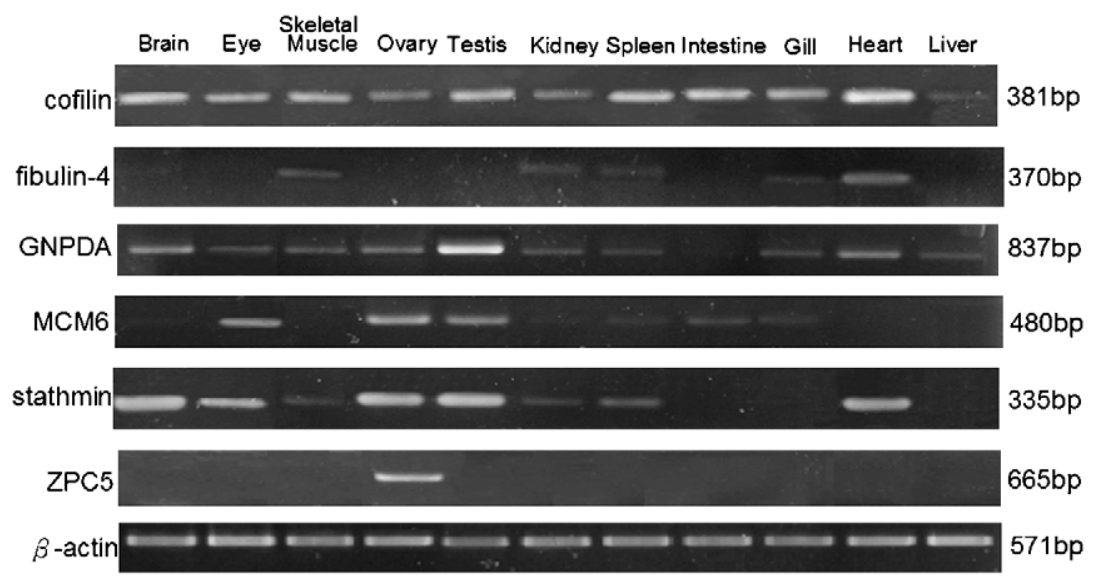

Fig. 3. RT-PCR analysis of development-and reproduction-related genes in adult tissues of Oreochromis mossambicus. RT-PCR was performed using respective primers and protocols as described in "Materials and methods" against products from 11 different tissues and analyzed on agarose gels stained with ethidium bromide. The PCR product sizes are listed on the right of each panel. In the bottom panel, $\beta$-actin expression was analyzed to show the homogeneity of different tissues. 


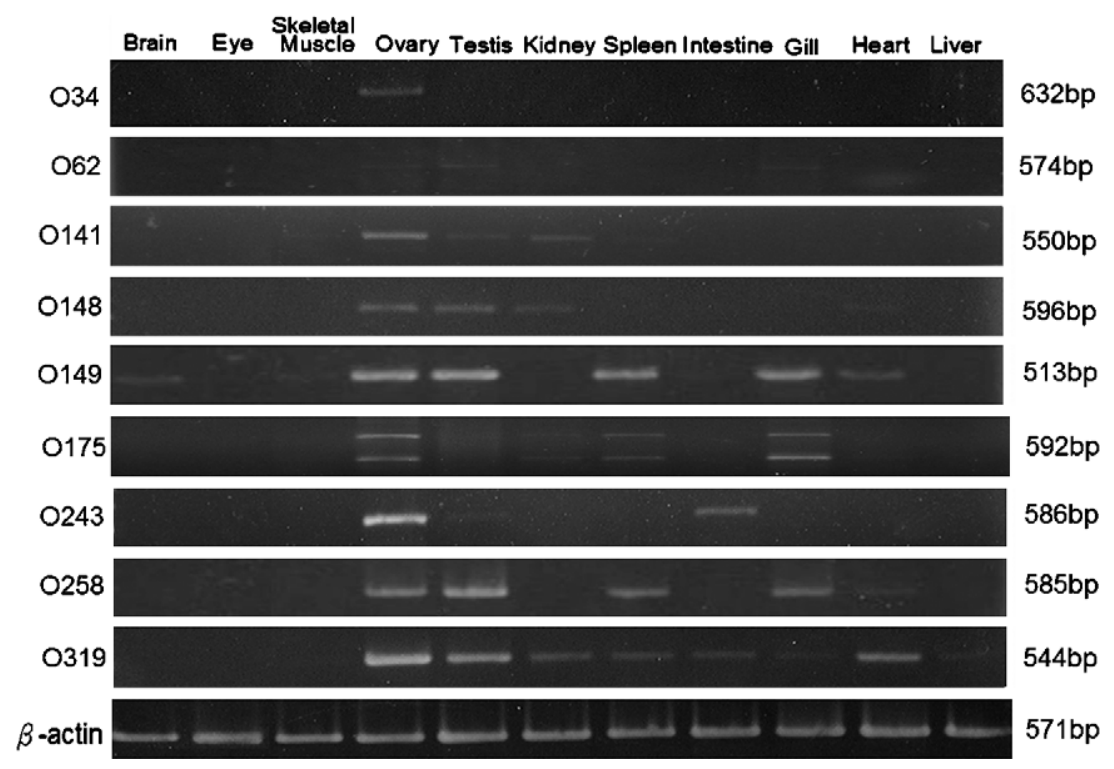

Fig. 4. RT-PCR analysis of the potential novel genes in adult tissues of Oreochromis mossambicus. RT-PCR was performed using the respective primers for 9 potential novel genes as designated and protocols as described in "Materials and methods" against products from 12 different tissues, and these PCR products were analyzed on agarose gels stained with ethidium bromide. The PCR product sizes are listed on the right of each panel. In the bottom panel, $\beta$-actin expression was analyzed to show the homogeneity of different tissues.

period of tilapia larvae on days $24 \sim 33$ (Tsai et al., 2000). For those larvae receiving regular feed (Fig. 5, control), most genes were expressed throughout the entire period examined, except for O141 and O148. The expression of O141 decreased on days 26 and 27, then rose again on days 30 and 33. In contrast, expression of $\mathrm{O} 148$ was not observed until day 30 . Furthermore, O149 exhibited the strongest expression.
Treatments with steroids during sex-sensitive periods are established means to control the sexual differentiation of tilapia (Tsai et al., 2000). To examine the effects of steroids on gene expression during sexsensitive periods, we treated larvae with $17 \beta$-estradiol $\left(\mathrm{E}_{2}\right)$ or $17 \alpha$-methyltestosterone (MT) to drive the sex of the fry towards being female or male, respectively, and the expression patterns of 6 gonad-specific

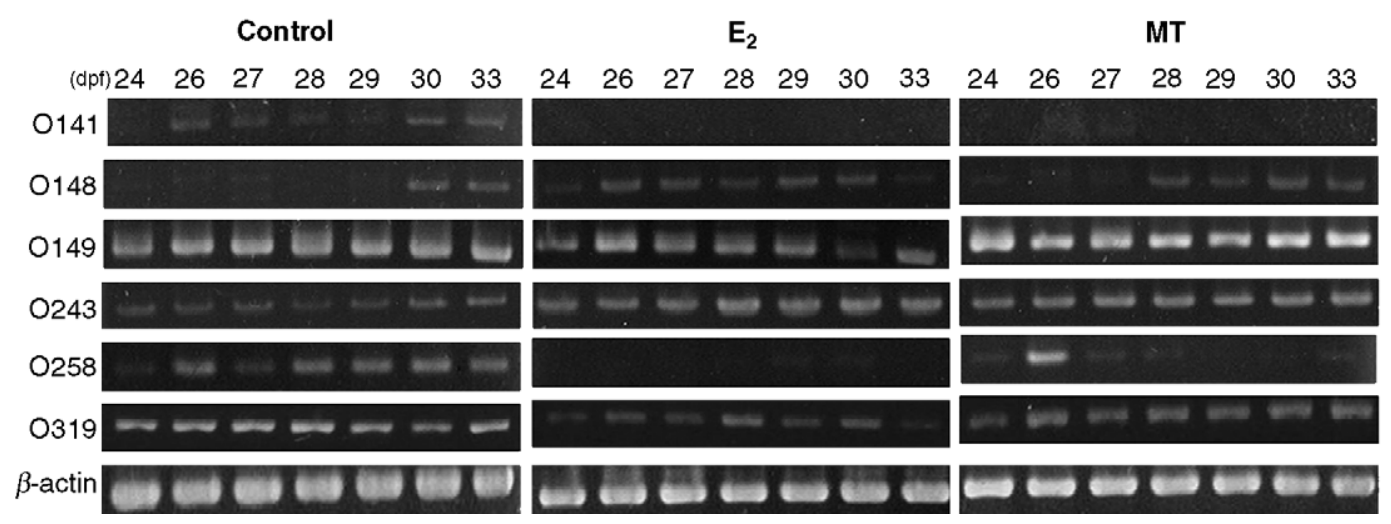

Fig. 5. RT-PCR analysis of the temporal expression of potentially novel genes in tilapia larvae during the sex-sensitive period. RT-PCR was performed as described in Fig. 4 against cDNAs from Oreochromis mossambicus larvae treated without (Control) or with $17 \beta$-estradiol ( $\mathrm{E}_{2}$ ) or $17 \alpha$-methyltestosterone (MT). PCR products were analyzed on agarose gels stained with ethidium bromide. The PCR product sizes are listed on the right of each panel. In the bottom panel, $\beta$-actin expression was analyzed to show the homogeneity of different tissues. 
novel genes were examined. For $\mathrm{E}_{2}$-treated larvae, the expressions of O141, O149, O258, and O319 were downregulated, whereas those of O148 and O243 were upregulated (Fig. 5; $\mathrm{E}_{2}$ ). For MT-treated larvae, the expressions of $\mathrm{O} 141$ and $\mathrm{O} 258$ were downregulated, whereas those of $\mathrm{O} 148, \mathrm{O} 149$, and $\mathrm{O} 243$ were upregulated (Fig. 5; MT).

\section{Discussion}

In this study, 768 random clones were sequenced and 474 tentative unique genes (TUGs) were identified, including 230 known genes. Among the known genes, only 6 of them have previously been reported in $O$. mossambicus. We were unable to annotate 244 $(51.5 \%, 244 / 474)$ unique sequences due to the low sequence homology or no significant match (44 clones) compared to existing known sequences in public databases. The high percentage of un-annotated sequences implies that the genetic diversity of tilapia is high compared to those species whose genomes have been well characterized. Those potentially novel genes may therefore be functionally important in fish in an evolutionary context.

These identified tilapia TUGs were classified into 13 broad biological process categories. The functional diversity of TUGs coincides well with the roles of the ovary in hormonal regulation of a variety of biological processes (Richards, 1994). Among the most-abundant genes, ferritin is widely distributed among vertebrates, plants, and bacteria, and functions mainly in iron metabolism (Hentze and Kuhn, 1996). Its role in reproduction is intriguing due to the importance of iron metabolism in both male and female fertility. Ferritin can be transported to gonads via the gonad intestinal loop (Beninger et al., 2003) or may be expressed in the gonads or oocytes as evidenced by the presence of ferritin genes in the Xenopus germinal vesicle oocytes (Huang et al., 2003). However, ferritin mRNA is not expressed in adult Galleria mellonella gonads (Kim et al., 2001) which argues against it having a role in the gonads. In this study, 2 independent TUCs were found, which represent the middle and lower subunits of ferritin, respectively (Table 3 ). Ferritin was also abundant in an adult tilapia testis library (our unpublished data). These results suggest that ferritin may play an important role in tilapia gonads. CDC28 protein kinase 1 and cyclin B are well-known cell cycle regulatory molecules. Calmodulin and the myosin light chain are also known as cell motility regulatory molecules. D7-like protein is an ovary-specific protein expressed in yellow perch and is homologous to KLRL1, a novel killer cell lectinlike receptor (Han et al., 2004). Lectins have been suggested to be involved in egg maturation and fertilization (Tateno et al., 2001). Two lectins have also been shown to be abundant in a zebrafish ovary library (Zeng and Gong, 2002). The abundance of lectin-like receptor genes in our tilapia ovary library is complementary to previous data and suggests a critical role of lectin signaling in the ovary. Cytokines are enriched in normal ovarian tissue and are important in the physiology of ovarian function and ovulation (Nash et al., 1999). The presence of interleukin12 in follicular fluid appears to negatively regulate the success of in vitro fertilization (Gazvani et al., 2000). The abundance of interleukin-12 in the tilapia ovary implies its conservative functions in fish. ZPC1 is homologous to a member of the egg envelope gene ZPC identified in medaka (Kanamori et al., 2003) and it has also been demonstrated to be rich in a zebrafish ovary library (Zeng and Gong, 2002). The last abundant TUG is homologous to a hypothetical protein, which has been predicted to be a nucleotide kinase involving nucleotide transport and metabolism. However, its role in regulating ovarian function is unclear.

To study genes which may be related to ovarian functions, 6 genes classified into the regulation of development and reproduction category were selected from this ovary library for a gene expression assay in different adult tilapia tissues. Cofilin is a molecule known to mediate actin depolymerization, which is important during embryogenesis (Ono, 2003; Ono et al., 2003). Fibulin-4 is a member of a versatile extracellular matrix protein family (Timpl et al., 2003) and mainly exists in the walls of capillaries and large blood vessels (Giltay et al., 1999). Glucosamin-6phosphate deaminase 2 (GNPDA/oscillin) is a protein of sperm extract, which was originally claimed to mediate the sperm-induced calcium oscillation in mammalian oocytes, but that was later proven to be wrong (Amireault and Dube, 2000). MCM6 is a member of the MCM2-7 proteins, which are important for chromatin assembly during DNA replication (Maiorano et al., 2000; Sible et al., 1998). Stathmin is 
a ubiquitous, neuron-enriched gene mediating tubulin depolymerization (Sobel et al., 1989). It was also demonstrated that maternal stathmin accumulates in oocytes and is redistributed in pre-implantation embryos (Koppel et al., 1999). ZPC5 is another egg envelope gene ZPC identified in medaka (Kanamori et al., 2003). Results show in tilapia that 1) GNPDA is predominantly expressed in the testis, 2) MCM6 is an ovary-and testis-specific gene, and 3) ZPC5 is exclusively expressed in the ovary. These 3 genes may therefore be useful markers for functional studies in gonads.

We also examined the spatial and temporal gene expression patterns of several potentially novel genes. All novel genes examined except 1 were strongly expressed in the ovary, thus confirming their ovarian origin. Four genes, including O141, O148, O243, and $\mathrm{O} 258$, exhibited a trend of increasing expression during the sex-sensitive period, and their expression patterns could be altered by steroid treatments (Fig. 5). These results suggest that these genes may be involved in sexual differentiation. However, determining the exact roles of these genes in sex differentiation requires further investigation.

From our analysis of ESTs from the tilapia ovary, it is very likely that a more-intensive sequencing effort will result in more gene sequences being identified. The functional characterization of ESTs from the adult ovary library of tilapia, O. mossambicus, will further our understanding of the molecular and physiological nature of the ovary. Expression profile analyses will also be important for comparative genomic and evolutional research of the gonads. More importantly, these data may provide a rich source for gene identification which is important for the sex manipulation technology that is frequently used in the culture of tilapia as well as other fishes.

\section{Acknowledgements}

We would like to thank Dr Y.C. Yang for help in analyzing data. We are also in debt to Dr. W.L. Liao for preparing the tilapia feed, Dr. S.W. Lou for supplying $17 \alpha$-methyltestosterone, and Dr. J.R. Hseu for providing the tilapia. This work was supported by the National Science Council of the R.O.C. (NSC912317-B-002-022 and NSC92-2317-B-002-024).

\section{References}

Adams, M.D., Kelley, J.M., Gocayne, J.D., Dubnick, M., Polymeropoulos, M.H., Xiao, H., Merril, C.R., Wu, A., Olde, B., Moreno, R.F., 1991. Complementary DNA sequencing: expressed sequence tags and human genome project. Science 252, $1651-1656$.

Amireault, P., Dube, F., 2000. Cloning, sequencing, and expression analysis of mouse glucosamine-6-phosphate deaminase (GNPDA/oscillin). Mol. Reprod. Dev. 56, 424-435.

Beninger, P.G., Le Pennec, G., Le Pennec, M., 2003. Demonstration of nutrient pathway from the digestive system to oocytes in the gonad intestinal loop of the scallop Pecten maximus L. Biol. Bull. 205, 83-92.

Davey, G.C., Caplice, N.C., Martin, S.A., Powell, R., 2001. A survey of genes in the Atlantic salmon (Salmo salar) as identified by expressed sequence tags. Gene 263, 121-130.

Douglas, S.E., Gallant, J.W., Bullerwell, C.E., Wolff, C., Munholland, J., Reith, M.E., 1999. Winter flounder expressed sequence tags: establishment of an EST database and identification of novel fish genes. Mar. Biotechnol. 1, 458-464.

Gazvani, M.R., Bates, M., Vince, G., Christmas, S., Lewis-Jones, D.I., Kingsland, C., 2000. Follicular fluid concentrations of interleukin-12 and interleukin-8 in IVF cycles. Fertil. Steril. 74, 953-958.

Giltay, R., Timpl, R., Kostka, G., 1999. Sequence, recombinant expression and tissue localization of two novel extracellular matrix proteins, fibulin-3 and fibulin-4. Matrix Biol. 18, 469-480.

Gong, Z., Yan, T., Liao, J., Lee, S.E., He, J., Hew, C.L., 1997. Rapid identification and isolation of zebrafish cDNA clones. Gene 201, 87-98.

Hamilton, L.C., Macpherson, G.R., Wright, J.M., 2000. Expressed sequence tags derived from brain tissue of Oreochromis niloticus. J. Fish Biol. 56, 219-222.

Han, Y., Zhang, M., Li, N., Chen, T., Zhang, Y., Wan, T., Cao, X., 2004. KLRL1, a novel killer cell lectin-like receptor, inhibits natural killer cell cytotoxicity. Blood 104 (9), 2858-2866.

Hentze, M.W., Kuhn, L.C., 1996. Molecular control of vertebrate iron metabolism: mRNA-based regulatory circuits operated by iron, nitric oxide, and oxidative stress. Proc. Natl. Acad. Sci. U. S. A. 93, 8175-8182.

Hirono, I., Aoki, T., 1997. Expressed sequence tags of medaka (Oryzias latipes) liver mRNA. Mol. Mar. Biol. Biotechnol. 6, $345-350$.

Huang, W.H., Guo, H.B., Huang, X.Y., Sun, F.Z., 2003. Two types of new ferritin cDNA sequences from Xenopus Laevis germinal vesicle oocytes. DNA Sequence 14, 211-214.

Inoue, S., Nam, B.H., Hirono, I., Aoki, T., 1997. A survey of expressed genes in Japanese flounder (Paralichthys olivaceus) liver and spleen. Mol. Mar. Biol. Biotechnol. 6, 376-380.

Ju, Z., Karsi, A., Kocabas, A., Patterson, A., Li, P., Cao, D., Dunham, R., Liu, Z., 2000. Transcriptome analysis of channel catfish (Ictalurus punctatus): genes and expression profile from the brain. Gene 261, 373-382.

Kanamori, A., Naruse, K., Mitani, H., Shima, A., Hori, H., 2003. Genomic organization of ZP domain containing egg envelope genes in medaka (Oryzias latipes). Gene 305, 35-45. 
Karsi, A., Cao, D., Li, P., Patterson, A., Kocabas, A., Feng, J., Ju, Z., Mickett, K.D., Liu, Z., 2002. Transcriptome analysis of channel catfish (Ictalurus punctatus): initial analysis of gene expression and microsatellite-containing cDNAs in the skin. Gene 285, 157-168.

Kim, B.S., Yun, C.Y., Yeo, S.M., Lee, H.J., Kim, H.R., 2001. Cloning and expression of a ferritin subunit for Galleria mellonella. Arch. Insect Biochem. Physiol. 47, 8-17.

Kocabas, A.M., Li, P., Cao, D., Karsi, A., He, C., Patterson, A., Ju, Z., Dunham, R.A., Liu, Z., 2002. Expression profile of the channel catfish spleen: analysis of genes involved in immune functions. Mar. Biotechnol. 4, 526-536.

Koppel, J., Rehak, P., Baran, V., Vesela, J., Hlinka, D., Manceau, V., Sobel, A., 1999. Cellular and subcellular localization of stathmin during oocyte and preimplantation embryo development. Mol. Reprod. Dev. 53, 306-317.

Maclean, N., Rahman, M.A., Sohm, F., Hwang, G., Iyengar, A., Ayad, H., Smith, A., Farahmand, H., 2002. Transgenic tilapia and the tilapia genome. Gene 295, 265-277.

Maiorano, D., Lemaitre, J.M., Mechali, M., 2000. Stepwise regulated chromatin assembly of MCM2-7 proteins. J. Biol. Chem. 275, 8426-8431.

Martin, S.A., Caplice, N.C., Davey, G.C., Powell, R., 2002. ESTbased identification of genes expressed in the liver of adult Atlantic salmon (Salmo salar). Biochem. Biophys. Res. Commun. 293, 578-585.

Millar, S.E., Lader, E., Liang, L.F., Dean, J., 1991. Oocyte-specific factors bind a conserved upstream sequence required for mouse Zona pellucida promoter activity. Mol. Cell. Biol. 11, 6197-6204.

Nash, M.A., Ferrandina, G., Gordinier, M., Loercher, A., Freedman, R.S., 1999. The role of cytokines in both the normal and malignant ovary. Endocr.-Relat. Cancer 6, 93-107.

Ono, S., 2003. Regulation of actin filament dynamics by actin depolymerizing factor/cofilin and actin-interacting protein 1: new blades for twisted filaments. Biochemistry 42 , $13363-13370$

Ono, K., Parast, M., Alberico, C., Benian, G.M., Ono, S., 2003. Specific requirement for two $\mathrm{ADF} /$ cofilin isoforms in distinct actin-dependent processes in Caenorhabditis elegans. J. Cell Sci. 116, 2073-2085.

Packer, A.I., Hsu, Y.C., Besmer, P., Bachvarova, R.F., 1994. The ligand of the c-kit receptor promotes oocyte growth. Dev. Biol. $161,194-205$.

Richards, J.S., 1994. Hormonal control of gene expression in the ovary. Endocr. Rev. 15, 725-751.

Richards, J.S., Rolfes, A.I., 1980. Hormonal regulation of cyclic AMP binding to specific receptor proteins in rat ovarian follicles. Characterization by photoaffinity labeling. J. Biol. Chem. 255, 5481-5489.

Shiue, Y.L., Wang, L.H., Chao, T.Y., Lin, C.H., Tsai, C.L., 2004. EST-based identification of genes expressed in the hypothalamus of adult tilapia, Oreochromis mossambicus. Biochem. Biophys. Res. Commun. 316, 523-527.

Sible, J.C., Erikson, E., Hendrickson, M., Maller, J.L., Gautier, J., 1998. Developmental regulation of MCM replication factors in Xenopus laevis. Curr. Biol. 8, 347-350.

Sobel, A., Boutterin, M.C., Beretta, L., Chneiweiss, H., Doye, V., Peyro-Saint-Paul, H., 1989. Intracellular substrates for extracellular signaling. Characterization of a ubiquitous, neuron-enriched phosphoprotein (stathmin). J. Biol. Chem. 264, 3765-3772.

Tateno, H., Ogawa, T., Muramoto, K., Kamiya, H., Hirai, T., Saneyoshi, M., 2001. A novel rhamnose-binding lectin family from eggs of steelhead trout (Oncorhynchus mykiss) with different structures and tissue distribution. Biosci. Biotechnol. Biochem. 65, 1328-1338.

Timpl, R., Sasaki, T., Kostka, G., Chu, M.L., 2003. Fibulins: a versatile family of extracellular matrix proteins. Nat. Rev., Mol. Cell Biol. 4, 479-489.

Tsai, C.L., Wang, L.H., Chang, C.F., Kao, C.C., 2000. Effects of gonadal steroids on brain serotonergic and aromatase activity during the critical period of sexual differentiation in tilapia, Oreochromis mossambicus. J. Neuroendocrinol. 12, 894-898; Tuttle, W.W., Schottelius, B.A., 1969. Textbook of Physiology, 6 ed. The C. V. Mosby Company, Saint Louis.

Zeng, S., Gong, Z., 2002. Expressed sequence tag analysis of expression profiles of zebrafish testis and ovary. Gene 294, $45-53$. 